\title{
"Onde o cidadão perdia o nome": A Colônia Correcional de Dois Rios e o estado de exceção
}

\author{
DOI: $10.15175 / 1984-2503-202012308$
}

\section{Ana Carolina Huguenin Pereira*}

\begin{abstract}
Resumo
A Colônia Correcional de Dois Rios (CCDR) surgiu em setembro de 1894, nas próprias origens da experiência penal republicana brasileira, autoritária e excludente. Nos anos 1930, nos quadros do estado de exceção, verificou-se o aumento sensível do contingente de correcionais, que passou a incluir centenas de prisioneiros políticos, entre os quais Graciliano Ramos e o jornalista Heron Pereira Pinto. Em suas memórias, ambos os autores compararam a Colônia a um campo de concentração. O presente artigo visa discutir a trajetória da CCDR enquanto espaço de exceção e produção da "vida nua", de acordo com referenciais teóricos propostos por Giorgio Agamben.
\end{abstract}

Palavras-chave: Colônia Correcional de Dois Rios; literatura de testemunho; Graciliano Ramos; Heron Pereira Pinto; Giorgio Agamben.

\section{"Donde el ciudadano perdía el nombre": la Colonia Correccional de Dois Rios y el estado de excepción}

\section{Resumen}

La Colonia Correccional de Dois Rios (CCDR) surgió en septiembre de 1894, en pleno nacimiento de la experiencia penal republicana brasileña, autoritaria y excluyente. En la década de 1930, durante el período del estado de excepción, tuvo lugar un aumento sensible del contingente de correccionales, que pasó a estar integrado por centenas de prisioneros políticos, entre ellos, Graciliano Ramos y el periodista Heron Pereira Pinto. En sus memorias, ambos autores comparan la colonia con un campo de concentración. El presente artículo tiene por objeto analizar la trayectoria de la CCDR como espacio de excepción y producción de la «vida desnuda», de acuerdo con los referentes teóricos propuestos por Giorgio Agamben.

Palabras clave: Colonia Correccional de Dois Rios, literatura testimonial, Graciliano Ramos, Heron Pereira Pinto, Giorgio Agamben.

\section{"Where citizens lost their names": Dois Rios Penal Colony and the state of exception}

\section{Abstract}

The Colônia Correcional de Dois Rios (CCDR) [Dois Rios Penal Colony] began its life in September 1894, at the very origins of the authoritarian and exclusionary penal experience of the Brazilian Republic. Within the context of the state of exception, a significant increase in the inmate population was recorded in the 1930s, which came to include hundreds of political prisoners, among them Graciliano Ramos and journalist Heron Pereira Pinto, who both compared the Colony to a concentration camp in their memoirs. The present article

\footnotetext{
* Professora Adjunta de História Contemporânea no Departamento de Ciências Humanas da FFP/UERJ; professora do quadro permanente do Programa de Pós-Graduação em História Social da UERJ, na linha de pesquisa Território, Identidades e Representações. E-mail: carolhuguenin@yahoo.com.br. http://lattes.cnpq.br/3745521194769377. (1) https://orcid.org/0000-0002-8527-649X.
} 
aims to discuss the CCDR's trajectory as a space of exception and for the production of "naked life", according to the theoretical frameworks proposed by Giorgio Agamben.

Keywords: Dois Rios Penal Colony; testimonial literature; Graciliano Ramos; Heron Pereira Pinto; Giorgio Agamben.

\section{" Là où le citoyen perdait son nom » : la Colonie correctionnelle de Dois Rios et l'état d'exception}

\section{Résumé}

La Colonie correctionnelle de Dois Rios (CCDR), qui a vu le jour en septembre 1894, dès les origines de l'expérience pénale républicaine du Brésil, était marquée par l'autoritarisme et l'exclusion. Dans les années 1930, dans le cadre de l'état d'exception, on a pu constater une augmentation significative des contingents de détenus, dont des centaines de prisonniers politiques parmi lesquels on retrouvait Graciliano Ramos et le journaliste Heron Pereira Pinto. Dans leurs mémoires, les deux auteurs comparèrent la Colonie en question à un camp de concentration. Le présent article entend discuter la trajectoire de la CCDR en tant qu'espace d'exception et de production de la « vie nue », conformément aux références théoriques proposées par Giorgio Agamben.

Mots-clés : Colonie correctionnelle de Dois Rios; littérature de témoignage ; Graciliano Ramos ; Heron Pereira Pinto ; Giorgio Agamben.

\section{公民在这里失去姓名和自由：两河昰教所与法外状态}

\section{摘要:}

1894年9月，巴西共和国政府在里约热内卢市郊区的两河镇建立了两河惩教所(Colônia Correcional de Dois Rios-(CDR)，专门收容并惩诫流浪者与社会上的违法犯罪分子。通过强制劳动，惩教所 试图改造这些流浪者和扰乱治安的社会人员。巴西旧共和时代 (1889-1930) 继承了巴西帝国 (18221889) 时代的威权主义传统，对惩教所的管理也采取了类似于过去的严厉的监狱式管理体制。在 1935年以后，由于巴西政府实施了紧急状态法，被收容惩诫的人员数量显著增加，甚至关押了数百 名政治犯，其中包括巴西作家格拉西利安诺·拉莫斯 (Graciliano Ramos) 和新闻记者埃隆·佩雷拉·平 托 (Heron Pereira Pinto)。两位作者在回忆录中都将惩教所与纳粹集中营进行了比较。本文旨在根 据乔治·阿甘本(Giorgio Agamben)提出的理论框架，分析CCDR惩教所的日常运转机制，在此机制 下，被惩戒人员在严密监视下的“裸露” 的日常生活，及其再生产。

关键词：两河惩教所；报告文学；格拉西利安诺·拉莫斯 (Graciliano Ramos)；埃隆·佩雷拉·平托 (Heron Pereira Pinto)；乔治·阿甘本 (Giorgio Agamben) 


\section{A República, a Colônia e o campo}

Em 1945, no contexto de queda do Estado de Novo, Graciliano Ramos (apud ALVES, 2016, p. 34) pronunciou, na célula partidária do PCB, um discurso dissonante, que questionava a aliança do Partido com Getúlio Vargas e evocava, neste sentido, a experiência carcerária:

Descontenta-nos a ideia de, encobertos nos remendos da carta meio fascista ainda existente, [...] eleger um ditador. [...] Desejamos trabalhar em sossego, livre das ameaças estúpidas que há dez anos transformaram isso numa senzala. $O$ nosso pequeno fascismo tupinambá encheu os cárceres e o campo de concentração da Ilha Grande [...] Usaremos todas as nossas forças para que essas infâmias não se repitam (grifo nosso).

Cerca de uma década mais tarde, a expressão "nosso pequenino fascismo tupinambá" (RAMOS, 2015 p. 12) seria anunciada novamente, desta vez direcionada aos leitores de todo o país, através da publicação póstuma de Memórias do Cárcere (1953). registro da vivência agônica de um período autoritário - demarcado enquanto fascista e ao mesmo tempo ironizado e diminuído segundo coordenadas locais ("pequenino", tupinambá") - transporta o leitor do Nordeste ao Sudeste do país, até o "campo de concentração da Ilha Grande".

No porão do navio Manaus, na "cova movediça", Graciliano (RAMOS, 2015, p. 135) realizou a travessia entre Recife e Rio de Janeiro. Na capital fora mantido junto a outros presos políticos, na Casa de Detenção do Distrito Federal, até a transferência, em junho de 1936, para a Colônia Correcional de Dois Rios (CCDR), em Ilha Grande. Espremidos no subsolo da embarcação, centenas de corpos, alguns dos quais recém-torturados, se amontoavam, oprimidos e sufocados: "punha-me a tossir [...] sufocado [...] levantava os braços e quase alcançava o teto baixo, a tampa de nossa catacumba" (RAMOS, 2015, p. 109). O interior da "catacumba" escondia e encerrava os "mortos", vítimas da repressão política que se seguiu ao Levante de 1935: "éramos fantasmas, rolaríamos de cárcere em cárcere, findaríamos num campo de concentração." (RAMOS, 2015 p. 160-161). Subtraídas a liberdade e todas as formas de dignidade, com as vidas subitamente interrompidas e para sempre marcadas pela experiência prisional, a condição dos encarcerados é identificada a uma condição mortal, à negação do que os constitui e identifica enquanto seres humanos, e que os conduz, no limite, à experiência concentracionária.

Ao emergir do "túmulo flutuante" e desembarcar no Rio de Janeiro, o escritor foi transferido, conforme referido, para a Casa de Detenção, e mantido junto a outros 
prisioneiros políticos - entre os quais Olga Benário, Nise da Silveira e Agildo Barata. Tratavam-se, em grande parte, de funcionários públicos, intelectuais, oficiais e profissionais liberais - pessoas cujas origens, vivência e visão de mundo não diferiam radicalmente daquelas do escritor. Algo bastante diverso, porém, o esperava no "campo de concentração de Ilha Grande", onde Graciliano se encontraria, ainda mais que outrora, em circunstâncias radicais de desumanização e mortificação. A perspectiva da transferência, que fatalmente viria, enchia o memorialista de horror e receio: "Por que [...] me mandavam para aquele inferno? [...]. Tencionavam corrigir-me na Colônia [...] onde guardam a canalha, o enxurro, vidas sórdidas" (RAMOS, 2015, p. 364).

"Aquele inferno" , a CCDR, surgira em setembro de 1894, nas próprias origens da experiência republicana brasileira, autoritária e excludente - mais especificamente, sob o governo Prudente de Moraes (1894-1898), encabeçado pelo primeiro presidente civil da jovem República, que se afirmou sob os auspícios do massacre de Canudos e do estado de sítio. O "inferno" insular era reservado, em suas origens, justamente a "vagabundos e malandros": pequenos contraventores criminalizados pelo Código Penal de 1890 mendigos e ébrios, prostitutas, vadios, menores infratores e capoeiras, em sua maioria negros e mestiços, a serem "corrigidos" através do trabalho (SANTOS, 2009). Em um contexto de modernização e reforma institucional, marcado pela nova ordem republicana e pela recente Abolição, a CCDR punia e isolava cidadãos considerados, na prática, de segunda categoria. Não integrados ao mercado livre de trabalho, os assim chamados "vagabundos" eram vistos enquanto ameaças à ordem instituída e ao "progresso" almejado: os "restos" indesejáveis e criminalizados da escravidão, homens e mulheres pobres, sem endereço fixo ou colocação formal, a serem removidos da capital "civilizada".

Meses após a inauguração da Colônia já despontavam denúncias de abusos e maus tratos. Em 21 de maio de 1895, o jornal Cidade do Rio, de José do Patrocínio, publicou o artigo Colônia de Dois Rios: Asilo de Infecção Moral. Afirma o texto:

[...] Há na llha Grande uma colônia denominada dos Dois Rios, criada no ano passado, durante o regime de estado de sítio, e destinada a asilo correcional de indivíduos delituosos. [...] mas, pelo que ali se observa, pelo modo por que se fizeram as remessas dos detentos para aquela casa, pelas práticas ali usadas, bem se vê que tal criação era destinada a atender outros fins, e que uma pequena Bastilha estava destinada a ser estabelecida na llha Grande, para depósito de todos os que incorressem no ódio dos governantes [...]. Na Colônia de Dois Rios existem 17 detentos, sendo 12 mulheres e 5 homens. Na maior parte foram para ali enviados sem forma alguma de processo, e isto desde setembro do ano passado. Uma simples ordem da autoridade desterrava para aquela prisão eterna os que incorressem na sua antipatia (COLONIA..., 1895, p. 1, grifo nosso.) 
Nos quadros do estado de sítio, do arbítrio policial e das prisões ilegais configurouse a "pequena Bastilha" (conforme o artigo denomina), na contramão dos valores liberais e democráticos que deveriam pautar a experiência republicana. A criação da Colônia procurava responder e encaminhar exigências de "correção" da vadiagem previstos no novo Código Penal, em consonância com a ética liberal do trabalho e da disciplina. Na prática, porém, fora erguida uma "Bastilha" isolada e aviltante, ou, de acordo com o que o jornal ainda aponta, um "asilo de infecção moral" distante dos objetivos de moralização e disciplinarização a que a Colônia a princípio se propunha.

As contradições entre legalidade e arbítrio, liberalismo e autoritarismo, Justiça e força policial perpassaram a trajetória da CCDR, sempre em detrimento dos deserdados da nova ordem republicana, que sobreviviam no frágil equilíbrio entre direitos de cidadania e o permanente (e no mais das vezes informal) estado de exceção a ameaçar as camadas populares. Segundo Santos (2009, p. 111), verifica-se, à época de criação da Colônia, constante tensão entre poder Judiciário e forças policiais:

\footnotetext{
Várias tentativas fracassadas foram feitas para diminuir o poder da polícia. Capoeiras eram enviados para Fernando de Noronha, e os cáftens deportados sem qualquer processo. Embora o Judiciário procurasse proibir a detenção sem processo, as condenações sem julgamentos eram comuns e os presos passavam anos na cadeia sem serem julgados.
}

Sempre às margens da legislação vigente, as péssimas instalações e condições precárias de alimentação e funcionamento da Colônia contrariavam os propósitos formais de sua criação. Novamente segundo denúncias publicadas em Cidade do Rio:

\begin{abstract}
Da vida em promiscuidade, repugnante, dos infelizes detentos dos dois sexos [...] resultam cenas em que a moral entra por muito pouco. Porém o que ainda mais grave torna a condição desses míseros reclusos são o desasseio, a imundície em que vivem imersos. Cobertos de parasitas pelo corpo inteiro, chagas, ostentando feridas causadas por maus tratos corporais, mal alimentados, andrajosamente vestidos [...]. Aos presos determina o regulamento que seja fornecida carne de vaca. Mas essa coisa eles nunca viram... Também Ihes deve ser fornecido pão ou bolacha; entretanto os pobres reclusos conhecem disso tanto quanto conhecem a carne de vaca. Ou por outra: dão-lhes bolacha: as mãos espalmadas (COLONIA..., 1895, p. 1).
\end{abstract}

A "pequena Bastilha", mais tarde conhecida pelo epíteto infamante de "caldeirão do Diabo", passou a receber, nas décadas que se seguiram à sua criação, quantidade crescente de correcionais - não apenas os pequenos contraventores de outrora, mas também prisioneiros políticos, sobretudo a partir dos anos 1930. Se em 1894 o número de detentos não ultrapassava 17 indivíduos, em sua maioria mulheres, ao final de 1936, ano em que Graciliano Ramos fora transferido para a Ilha Grande, às vésperas do Estado Novo 
e sob forte repressão comandada pelo chefe de polícia Filinto Muller, o total de correcionais, segundo dados levantados por Myrian Sepúlveda dos Santos (2009) chegou a 1.388 homens, mais que quadruplicando em relação ao ano anterior, o que demostra "a importância que a Colônia alcançara ao longo dos anos. De lugar de confinamento de pequenos contraventores no início do século [...] tornara-se um dos principais locais de detenção, não só de presos políticos, mas de presos comuns.” (SANTOS, 2009, p. 215). A má alimentação, a fome, as doenças e os maus tratos, denunciados ainda em 1895, permaneciam. A esta altura, porém, atingiam não apenas "malandros e vagabundos" (conforme Graciliano se refere aos prisioneiros "comuns"), mas também prisioneiros políticos, em geral letrados e advindos das camadas médias e cultas. 


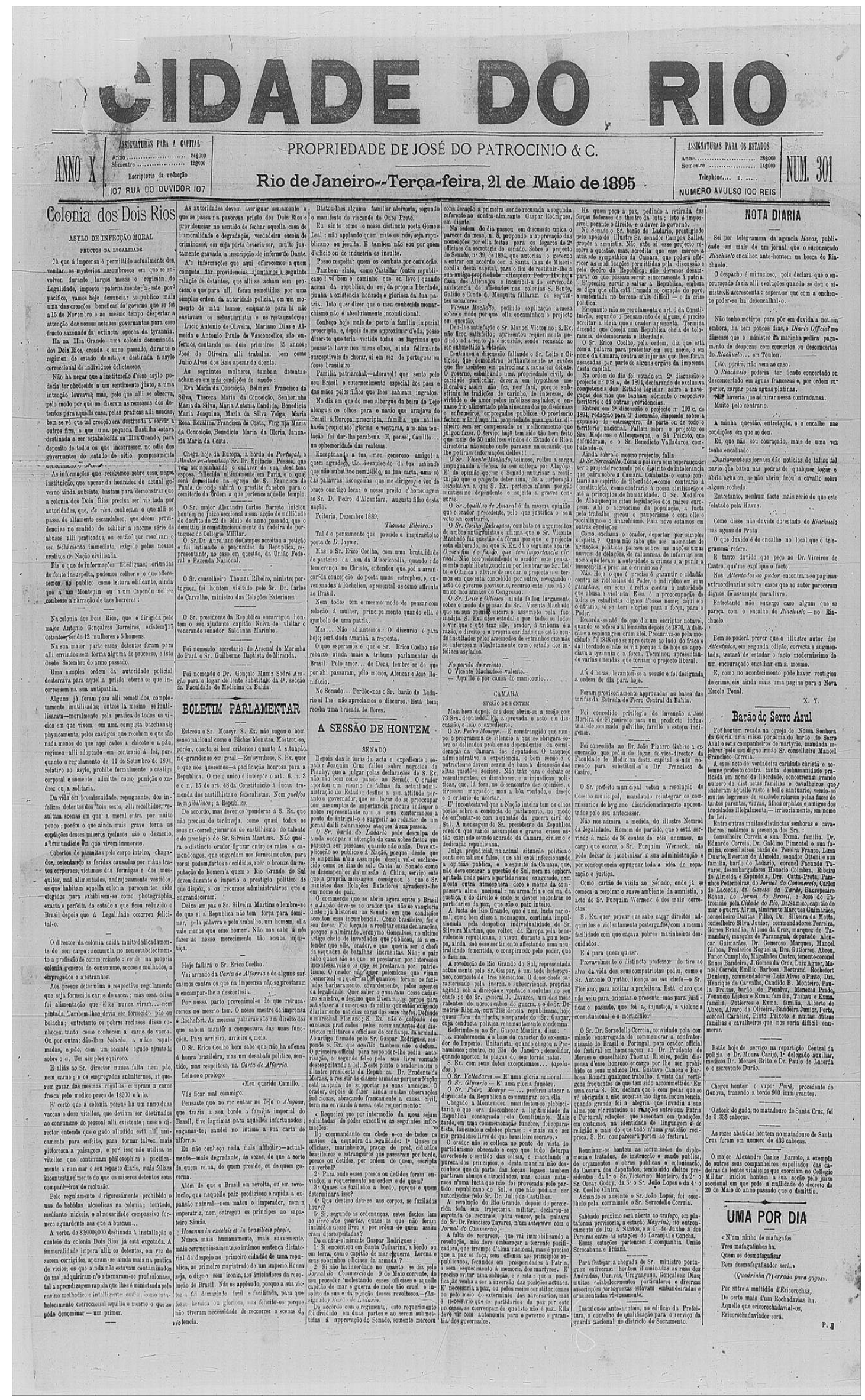

Fonte: (COLONIA..., 1895, p. 1 [online]). 


\section{"Onde o cidadão perdia o nome"}

Se o país, conforme Graciliano expressara em seu discurso ao PCB, havia se "transformado numa senzala", é deste autoritarismo que emergem as figuras sombrias que povoam as Memórias: presos políticos em meio ao estado de guerra, às vésperas do Estado Novo, encarcerados ao arrepio do devido processo legal. O próprio romancista não fora formalmente processado ou ao menos interrogado: a experiência de encarceramento ocorreu às margens do ordenamento jurídico e do controle judiciário, lançando o escritor numa experiência de marginalidade radical: no "campo de concentração" da "ilha dos suplícios" (PINTO, 1950), enquanto preso político nos quadros do estado de exceção.

Segundo Giorgio Agamben (2010, p. 25), a situação de exceção gera um contexto limítrofe entre inclusão e exclusão, não podendo ser definida

[...] nem como situação de fato nem de direito, mas institui[ndo] entre estas um paradoxal limite de indiferença. Não é um fato, porque é criado apenas pela suspensão da norma; mas, pela mesma razão, não é ao menos um caso jurídico, ainda que abra a possibilidade de vigência da lei.

Ainda segundo o autor, "quando nosso tempo procurou dar uma localização visível para este ilocalizável, o resultado foi o campo de concentração" (AGAMBEN, 2010, p. 26). Na contramão do Estado de direito, o estado de exceção não se vincula ao direito carcerário enquanto um ramo específico do direito penal, integrante do ordenamento normal - daí a emergência de espaços de reclusão específicos, orientados pela lei marcial ou pelo estado de sítio e essencialmente distintos daqueles analisados por M. Foucault em Vigiar e Punir. O campo seria o espaço por excelência de produção da "vida nua", do desnudamento radical de direitos e de eliminação da vida "politicamente qualificada" (AGAMBEN, 2010, p. 10) através do exercício do poder soberano, que decide sobre, e implementa o, estado de exceção.

Graciliano descreve como um "curral de arame" (RAMOS, 2015 p. 380) o pátio de areia molhada, cercado de arame farpado, onde se amontoavam presos famintos e exaustos em decorrência de trabalhos forçados, infestados por doenças e parasitas, oprimidos pela brutalidade e pela insalubridade que marcavam as instalações da Colônia. Figuras animalizadas e despersonalizadas como "bonecos" (RAMOS, 2015 p. 414); "bichos miúdos" (RAMOS, 2015 p. 420); "frangalhos, fontes secas, egoísmos cheios de pavor" (RAMOS, 2015 p. 426); "carneiros", "tropel de bichos mansos na areia molhada" RAMOS, 2015 p. 426). Tratava-se de um espaço de desumanização e produção da "vida nua" à qual 
o escritor fora reduzido, junto a outros presos políticos, devidamente advertidos por um "tipinho de farda branca" (RAMOS, 2015, p. 429):

- Aqui não há direito. Escutem. Nenhum direito. Quem foi grande, esqueça disto. Aqui não há grandes. Tudo igual. Os que têm protetores ficam lá fora. Atenção. Vocês não vêm corrigir-se, estão ouvindo? Não vêm corrigir-se, vêm morrer. (RAMOS, 2015 p. 429)

O espaço de reclusão que elimina o direito, para o qual o escritor fora enviado às margens (e a despeito) do ordenamento jurídico, é o espaço da morte, onde muitos de seus companheiros, a exemplo dele mesmo, sucumbem - doentes, desmoralizados e exaustos - se aproximando dos, quando não ultrapassando os, limiares da vida. Daí a comparação da Colônia a um campo de concentração, ao espaço de exceção que elimina o direito, e onde "tudo é igual", se equivalendo nos quadros da advertência reiterada: "aqui não há direito, não vêm corrigir-se, vêm morrer".

Diante da ameaça, Graciliano (RAMOS, 2015, p. 429) observa:

Embora não me restasse ilusão, a franqueza nua [do guarda] abalou-me. [...] suprimiam-nos de chofre qualquer direito e anunciavam friamente o desígnio de matar-nos. Singular. Constituíamos uma sociedade numerosa, e não tínhamos nenhum direito, nem ao menos o direito de viver. [...] Várias pessoas estavam ali sem processo [...]: não havia julgamento e expunham claro o desejo de assassinálas. Os soldados podiam jogar-nos impunemente no chão, rolar-nos a pontapés. $E$ finar-nos-íamos devagar. [...]. em vez de metermo-nos no forno crematório, iam destruir-nos pouco a pouco.

Ao narrar sua experiência na Colônia Correcional, o jornalista Heron Pereira Pinto, preso em 1935 e enviado à CCDR em maio de 1936, aproximadamente um mês antes de Graciliano, afirma:

A repressão na Colônia é simplesmente desumana, cruel, brutal.

Só mesmo nos campos de concentração da Alemanha ou da Itália, países líderes do fascismo, cujo lema é oprimir espiritual, moral e materialmente os povos, se reproduzem os dramas de escravismo, em pleno século XX, desenrolados ali, vividos por milhares de cidadãos cativos, de cabeças raspadas, braços cruzados e atirados em celas frias que, em poucos dias, inutilizam o homem mais robusto. (PINTO, 1950, p. 39).

Ou ainda:

Uma ilha que fica no continente cercada de vegetação espessa [...]; um telhado de zinco chorando gotas enervantes de chuva: a areia fria, a fome, a opressão, as paredes esburacadas deixando passar livremente as rajadas violetas de friagem, os terríveis parasitas; os homens seminus e molhados: ameaças, cacete e bofetões. Eis a fotografia do campo de concentração nazifascista sustentado por Getúlio Vargas (PINTO, 1950: p. 53). 
A equiparação exata e direta da Colônia Correcional a campos de extermínio nazistas é uma extrapolação. O caráter sistemático, planejado e articulado a partir do qual se produzia cadáveres em série, em espaços de exceção como Auschwitz, é marca específica das "fábricas da morte" geridas pelo Estado nazista, nos quadros burocráticos e partir da fria competência administrativa que constituem e potencializam a "banalidade do mal” (ARENDT, 2014). Conforme observa Graciliano, na Colônia Correcional não havia fornos crematórios: os correcionais, ainda segundo o autor, seriam mortos "pouco a pouco" (RAMOS, 2015, p. 429). Isto é, não havia execuções sumárias, e não se produzia dezenas de cadáveres instantaneamente, a partir de um expediente técnico, do acionar de um mecanismo. Nos campos de extermínio os prisioneiros eram assassinados de forma quantitativa e qualitativamente inédita, massificada e sistematizada - a morte seria a única perspectiva, e mesmo esta se apresentava de forma particularmente perversa, sob o signo da produção seriada de corpos.

Fabricação de cadáveres implica que já não se possa falar em morte, [...] mas algo infinitamente mais ultrajante que a morte. Em Auschwitz não se morria: produziamse cadáveres. Cadáveres sem morte, não-homens cujo falecimento foi rebaixado à produção em série. É precisamente a degradação da morte que constituiria, segundo uma possível e difundida interpretação, a ofensa específica de Auschwitz, o nome próprio do seu horror (AGAMBEN, 2008, p. 78).

É no contexto do ultraje radical à dignidade, na vida e na morte, que a SS referia-se aos milhares de cadáveres anônimos, simplesmente, como "figuras" (AGAMBEN, 2008, p.77) - destituídas de formas ou feições particulares, humanas. Ainda segundo Agamben (2008, p. 77), "Aushwitz é exatamente o lugar em que o estado de exceção coincide, de maneira perfeita, com a regra, e a situação extrema converte-se no próprio paradigma do cotidiano". Na Colônia, por sua vez, a correspondência não era exata. A morte estava mais relacionada à desorganização, à negligência e a insuficiências de toda sorte - material, humana e administrativa - que à produção sistemática e organizada de "cadáveres sem morte". Não deixa de ser significativa e pertinente, não obstante, a comparação proposta por Graciliano e Heron Pereira Pinto da CCDR não exatamente aos campos de extermínio, mas aos campos de concentração.

Cercados de arame farpado, vestidos em andrajos e despidos de seus direitos fundamentais, os prisioneiros tinham as cabeças raspadas e os nomes substituídos por números. Na "formatura geral" (a ordenação dos correcionais em filas de contagem, verificação e deslocamentos, as quais se repetiam várias vezes ao dia) os presos deveriam manter as cabeças raspadas abaixadas, guardando os braços cruzados e o silêncio, para 
responder apenas quando eram chamados - não pelos nomes, mas pelos números que Ihes eram atribuídos: Graciliano recebeu então seu "número de batismo" (RAMOS, 2015 p. 436): - "3535. Não se esqueça." (RAMOS, 2015 p. 435).

A respeito da "formatura geral" Heron P. Pinto (1950, p. 39-40) testemunha:

Escoltados por um grupo da Força Militar em turmas de trinta homens [os presos] eram entregues ao famoso verdugo [ o anspeçada] Aguiar. À esquerda de um barracão, cujo piso era de areia molhada, coberta de maltratadas folhas de zinco, um quadrado de arame farpado dava o aspecto nítido e aterrante de um campo de concentração. Em derredor, soldados de armas embaladas calavam baionetas sob comando de um cabo:

- Formatura geral! - esganiçava o anspeçada. [...]. Dentro em breve, 400 presos políticos em promiscuidade aviltante com mais 300 presos comuns [...] penetravam num barracão infecto e repugnante. $O$ chão de areia molhada propositadamente par aniquilar os presos políticos [...] ali o cidadão perdia o nome para vê-lo substituído por números.

O cidadão que perdia o nome perdia os direito e garantias individuais: perdia, de fato, a própria a cidadania. Deste modo, ficava à mercê da violência arbitrária exercida por "homenzinhos" como o pequeno anspeçada - que se tratava, segundo Graciliano (RAMOS, 2015, p. 416), de um sujeito

[... ] nanico, [que] tinha péssimas entranhas, [e] compensava a escassez física normalizando a violência; arrogava-se poder imenso, de fato ali dentro superava as autoridades comuns, adstritas à censura e a regras. Exigia respeito absurdo, e na presença dele todos nós deveríamos guardar silêncio e cruzar os braços. Difícil admitir que tal insignificância tivesse meios de criar normas, sujeitar a elas várias centenas de indivíduos.

Na ausência das normas vigentes, no âmbito do espaço de exceção, o "nanico" soldado criava as próprias regras, às quais eram submetidos centenas de homens, grande parte dos quais encarcerados sem processo formal. Ainda sobre o arbítrio do anspeçada, Heron Pereira Pinto (1950, p. 40) relata:

Após formatura geral, desumana, mais de trinta vezes durante aquele dia de pé, braços cruzados, o verdugo Aguiar, da Polícia Militar, pequenino, arrogante, de mentalidade estreita, falou a 700 homens, desafiando-os com o olhar [...].

- Disciplina, do contrário, temos ordens severas.

O "homenzinho" esclarece quais seriam as "ordens severas", enquanto brandia "um cacete maior do que ele próprio. [...]. - Silêncio! Não quero barulho. Tenho ordens de agir e até de matar. São ordens de 'cima"” (PINTO, 1950, p. 42). As "ordens de cima” não restringiam, em conformidade com a Lei, mas autorizavam e estimulavam o pequeno anspeçada a brandir o porrete e dar livre vazão aos instintos sádicos, à perversidade a partir da a qual se organizava as vidas dos homens confinados no "curral de arame": 
$\mathrm{Na}$ escuridão do barracão, entre as exalações fétidas de 700 presos vivendo em promiscuidade, os quais não podem ter a menor higiene, surgia o algoz Aguiar, encapotado, de cacete na mão, olhando-nos com sadismo. Passara algumas horas ideando novas torturas e vinha expandir as suas taras de psicopata sobre inermes cidadãos cativos, vítimas da ditadura getuliana (PINTO, 1950, p. 50).

Um correcional seminu, de olhos abaixados e braços cruzados (conforme exigência do "psicopata") tiritava de febre e frio e implorava para ser liberado do banho, alegando, neste sentido, recomendação do médico do presídio, o Doutor Hermínio Ouropretano Sardinha. Segue-se a resposta: - "Aqui não tem médico nenhum. Quem manda no presídio sou eu. Vai já para o banho - do contrário, segue para a cela [de castigo]" (PINTO, 1950, p. 50).

Neste sentido, Heron P. Pinto (1950, p. 40) indaga: “Onde estavam as nossas conquistas jurídicas? Onde estava o respeito constitucional aos comezinhos direitos dos cidadãos? Era o prólogo da tragédia da ditadura". Finalmente, a respeito dos "direitos" que restariam aos presos, o jornalista observa: "Pelados, sem alimentação, sem agasalho, quase nus, obrigados a dormir sobre a areia molhada, os escravos da ditadura só tinham o direito de sufocar, recalcar, odiando." (PINTO, 1950, p. 43.). Afinal, e mais uma vez, "aqui não há direitos".

Por outro lado, o "curral de arame" não cercava apenas prisioneiros políticos ou detentos que, a exemplo de Graciliano, não haviam enfrentado condenação formal: havia, conforme mencionado, prisioneiros "comuns", formalmente processados e enviados, em tese, para serem "corrigidos". A CCDR, portanto, se inscrevia no direito carcerário, não constituindo apenas um "campo de concentração" no sentido próprio do termo, mas reunia a experiência de encarceramento às margens e, ao mesmo tempo, na forma das leis vigentes. Em todo caso, os detentos, formalmente condenados ou não, por crimes "comuns" ou de natureza política, se deparavam com abusos de toda sorte, no âmbito de uma experiência desumanizante incompatível com o direito penitenciário formalizado na letra - morta - das leis.

É a partir desse contexto de abuso e de vivência do trauma, que Graciliano Ramos e Heron Pereira Pinto, enquanto sobreviventes, deixaram seus relatos, seu testemunhos, que trazem à tona e denunciam experiências carcerárias traumáticas e desumanizantes incluindo a submissão dos presos, políticos e "comuns", a castigos corporais e à prática de tortura perpetrados pelo poder estatal, em meio ao estado de exceção, à violência e ao autoritarismo políticos, que negam e subtraem direitos básicos. 


\section{"O que resta" da CCDR: História e testemunho em Memórias do Cárcere}

Ao discutir a relação entre memória, história e literatura, Marcio Seligmann-Silva (2003) afirma que a historiografia possui elementos para "corrigir" imprecisões inerentes ao processo de recordação, presentes, com frequência, na evocação de vivências traumáticas: "A historiografia corrige o elemento unilateral da memória - que é, a um só tempo, individual e unilateral aos conceitos e generalizações e faz parte da construção da memória individual e coletiva" (SELLIGMAN-SILVA, 2003, p. 16). Nesse sentido, o autor propõe situar o testemunho no "vértice entre a história e a memória, entre os fatos e as narrativas, entre, em suma, o simbólico e o indivíduo" (SELLIGMAN-SILVA, 2005, p. 82), entre a experiência coletiva e a vivência do sujeito. Contemplando este vértice, ao nos debruçarmos sobre o teor testemunhal da literatura,

[...] a equação sujeito-mundo não é mais resolvida de um modo simplista: a balança ora pende para o lado subjetivo - discurso sobre a memória individual, a autobiografia, a construção do passado como reconstrução individual, etc. - ora para o objetivo - o "real" como algo que molda a linguagem e escapa a ela, a memória coletiva como discurso de construção de uma identidade que se dá em uma negociação nos planos político e estético (SELLIGMAN-SILVA, 2003, p. 42).

Entre os planos político e estético, subjetivo e coletivo, entre História e Memória, se situam as Memórias do Cárcere, enquanto literatura de testemunho. A descida aos "porões da república" (SANTOS, 2009), a experiência (e o registro dessa experiência) "subterrânea" do cárcere, vivenciada pelo escritor em um contexto de modernização do país e de fabricação de uma nova identidade nacional sob o governo Vargas, fazem parte da essência - e da contribuição histórica - das Memórias.

Segundo Marcelo Ridenti (2014, p. 481),

As Memórias do cárcere podem ser interpretadas como um testamento literário. 0 autor registrou seu intento de ser lembrado como uma pedra no caminho dos poderosos, uma voz dissonante do coro dos contentes, que incomodava não propriamente pela militância política, mas por afirmar sua autonomia de escritor, livre para criticar e expor as cicatrizes sociais. Graciliano Ramos relatava seu malestar não só em relação à experiência na cadeia, mas também com sua própria vida em meio à modernização da sociedade brasileira.

O testemunho de Graciliano, portanto, enquanto “testamento literário' se colocaria como uma "pedra no caminho" quando se trata de celebrar consensos e, num processo inerente à seletividade da memória coletiva, silenciar as chamadas "memórias subterrâneas", não "enquadradas" (ao menos num primeiro momento) no processo seletivo 
de construção da memória nacional (POLLAK, 1989). De acordo com Alfredo Bosi (1995, (1995, p. 309)), as Memórias do Cárcere são

[...] um depoimento à história política brasileira dos anos [19]30" - no caso, marcada pela violência política inerente ao estado de exceção. Na obra, "a memória dos fatos históricos se fez construção literária pessoal sem descartar o compromisso com o que é vulgarmente compreendido com o que se entende por realidade objetiva".

Para tanto, o relato de Graciliano apresenta teor testemunhal, que abarca, insistese, de forma complexa e multifacetada, as dimensões artístico-literária, subjetiva (isto é, conscientemente relacionada a memórias, impressões e sentimentos individuais) e histórica. Ainda segundo Bosi, "o testemunho quer-se idôneo, quer-se verídico, pois aspira a certo grau de objetividade" (BOSI, 1995, p. 309). Tal objetividade, a relação direta e o compromisso reiterado com as condições objetivas, com o contexto externo que cerca, oprime e desafia a todo o instante o sujeito que testemunha, ou que sobreviveu à experiência traumática para testemunhá-la, não exclui - e não poderia excluir, por definição - o próprio sujeito. Ou seja, a dimensão subjetiva se entrelaça ao contexto exterior, inscrito no quadro mais amplo de um determinado período histórico, e, através de um filtro consciente, individual e artístico, deixa o seu registro. Assim, ainda segundo o autor, a literatura de testemunho

[...] casa memória individual com história. Mas o testemunho também se sabe a obra de uma testemunha, que é sempre um foco singular de visão e elocução. Logo, o testemunho é subjetivo, e, por esse lado, se aparenta com a narrativa literária em primeira pessoa. [...].

As Memórias do cárcere dão o paradigma dessa complexidade textual. Ao percorrêlas, somos levados tanto a reconstituir a fisionomia e os gestos de alguns companheiros de prisão de Graciliano, quanto a contemplar a metamorfose dessa matéria em prosa una e única - a palavra no narrador (BOSI, 1995, p. 309-310).

A palavra, portanto, é do narrador - que reconstitui e nos dá acesso à "fisionomia e aos gestos dos companheiros de prisão", de outro modo relegados ao esquecimento ou ao completo desaparecimento, quando se trata, principalmente, de anônimos prisioneiros "comuns" da Colônia Correcional de Dois Rios. A palavra funciona ainda como uma espécie de filtro entre a experiência coletiva, o mundo exterior e a experiência histórica de um período autoritário, e, por outro lado, a vivência individual, no exercício de rememoração e evocação do drama vivido pessoal e coletivamente. Do processo de desumanização inédito e radical desencadeado em Auschwitz, Agamben (2008) deriva a seguinte lição: "não é possível destruir integralmente o humano. Algo sempre presta, A testemunha é esse resto." (AGAMBEN, 2008, p. 136). Se, ainda segundo o autor, a testemunha é "o que resta de 
Auschwitz", podemos contemplar os textos testemunhais de autores como Graciliano Ramos e Heron Pereira Pinto como "o que resta" da experiência desumanizante e silenciadora da Colônia Correcional, do esquecimento e do anonimato que recaiu, ao longo de décadas, sobre prisioneiros anônimos que jamais deixaram seus relatos.

\section{Fontes}

PINTO, Heron Pereira. Nos subterrâneos do Estado Novo. Rio de Janeiro: Germinal, 1950. RAMOS, Graciliano. Memórias do cárcere. São Paulo: Record, 2015.

COLÔNIA Dois Rios: Asilo de Infecção Moral, Frutos da Legalidade. Cidade do Rio, Rio de Janeiro, Anno X, n. 301, p. 1, 21 maio 1895. Disponível em: http://memoria.bn.br/DocReader/085669/4262. Acesso em: 12 dez. 2019.

\section{Referências}

ALVES, Fábio César. Armas de papel: Graciliano Ramos, as Memórias do Cárcere e o Partido Comunista Brasileiro. São Paulo: Ed. 34, 2016.

AGAMBEN, Giorgio. O que resta de Auschwitz: o arquivo e a testemunha (Homo Sacer III). São Paulo: Boitempo, 2008.

AGAMBEN, Giorgio. Homo sacer: o poder soberano e a vida nua. Belo Horizonte: UFMG, 2010. v. 1.

ARENDT, Hannah. Eichmann em Jerusalém: um relato sobre a banalidade do mal. São Paulo: Companhia das Letras, 2014.

BOSI, Alfredo. A escrita de testemunho em Memórias do Cárcere. Estudos Avançados, São Paulo, v. 9, n. 23, p. 309-322, jan./abr. 1995. http://dx.doi.org/10.1590/S010340141995000100020

FOUCAULT, Michel. Vigiar e punir : história da violência nas prisões. 40 ed. Petrópolis, RJ: Vozes, 2012.

POLLAK, Michael. Memória, esquecimento, silêncio. Estudos Históricos, Rio de Janeiro, v. 2, n. 3, $\quad$ p. 3-15, 1989. Disponível em: http://bibliotecadigital.fgv.br/ojs/index.php/reh/article/view/2278. Acesso em: 20 dez. 2019.

RIDENTI, Marcelo. Graciliano Ramos e suas Memórias do cárcere: cicatrizes. Sociologia \& Antropologia, Rio de Janeiro, v. 4, n. 2, p. 475-493, jul./dez. 2014. https://doi.org/10.1590/2238-38752014v427

SANTOS, Myrian Sepúlveda dos. Os porões da República: a barbárie nas prisões da Ilha Grande: 1884-1945. Rio de Janeiro: Garamond, 2009.

SELIGMANN-SILVA, Marcio. História, Memória, Literatura. Campinas: Unicamp, 2003. 
Passagens. Revista Internacional de História Politica e Cultura Jurídica

Rio de Janeiro: vol. 12, ${ }^{0}$ 3, setembro-dezembro, 2020, p. 496-511.

SELIGMANN-SILVA, Marcio. Testemunho e a política da memória: o tempo depois das catástrofes. Projeto História, São Paulo, v. 30, p. 71-98, 2005. Disponível em: https://revistas.pucsp.br/index.php/revph/article/view/2255. Acesso em: 21 dez. 2019. 